Discourse and Communication for Sustainable Education, vol. 9, no. 1, pp. 128-142, 2018

\title{
Eco-Schools Indian Ocean: Relating Contemporary ESD Theory to Real Change on the Ground
}

\author{
Olivia Copsey \\ Independent Consultant in ESD, United Kingdom
}

\begin{abstract}
Several high-level strategies devote special priority to Education for Sustainable Development (ESD) in Small Island Developing States (SIDS). Given the seriousness of the ESD agenda in SIDS, it is vital that ESD programmes perform at a level where potential positive impacts on schools and communities can be realised. Contemporary literature on ESD has shed light on the most effective educational approaches for addressing the types of complex sustainability problems facing islands. This study set out to identify the types of changes which Indian Ocean ESD professionals are working towards on the ground, and how these relate to contemporary ESD theory. Despite the practical and urgent issues facing Indian Ocean SIDS, this research reveals a general rejection of traditional expert-driven instrumental/behaviourist approaches in favour of a dominant emancipatory approach and full grasp of the need for transformative change and a holistic 'whole institution approach' to ESD among ESD professionals in the Indian Ocean. The study goes on to illuminate how the professionals believe transformative change can be recognisable in Indian Ocean schools, and finally proposes four indicators for evaluation.
\end{abstract}

Keywords: education for sustainable development, ESD, transformative education, ESD evaluation, small Island developing states, eco-schools.

\section{Introduction}

Communities on SIDS are operating in the context of climate change at the 'sharp end' (Crossley \& Sprague, 2013), and already experiencing its damaging day-to-day effects, including sea-level rise, soil erosion, flooding, water shortages, and high frequency of natural disasters. These endanger their livelihoods, health and wellbeing, and in some cases, threaten their very existence (UN, 2005). This article outlines the results of research carried out within five Indian Ocean island nations: Comoros, Madagascar, Mauritius, Seychelles and Zanzibar which focussed on the European Union funded Eco-Schools Indian Ocean programme, coordinated by the author. Eco-Schools Indian Ocean was introduced in 2015 by the Indian Ocean Commission (IOC) ISLANDS project as a regional framework to integrate Education for Sustainable Development (ESD) 
into national education systems, supporting delivery of national sustainable development strategies, UNESCO's Global Action Programme (GAP), and the UN Sustainable Development Goals. As the primary programme for ESD in each country, Eco-Schools must be able to meet all objectives and ultimately support the practical and urgent challenges facing communities on the ground. This is especially important as the marker of ESD implementation in some countries has become 'percentage uptake' of the Eco-Schools programme. However, amongst those implementing Eco-Schools (some 88 multi-disciplinary 'National Eco-Schools Committee' members) a variety of objectives, priorities and educational approaches exists. In view of the growing body of ESD research and theory which suggests that some approaches are better than others, this study sets out to identify clearly the objectives and priorities of those implementing Eco-Schools, in order to identify if the programme is theoretically able to deliver the level of change required in Indian Ocean SIDS.

\section{Literature Review}

Contemporary literature on ESD distinguishes between two dominant perspectives, the instrumental/behaviourist view, characterised by an expert driven approach which focuses on an external outcome, as opposed to the emancipatory/intrinsic view which emphasises nurturing qualities within the learner (Wals, 2010; Sterling, 2010; Tilbury \& Janousek, 2007). The difference between these views is used in this study to define the educational approach and expected outcomes of ESD professionals implementing the Eco-Schools Indian Ocean programme.

The instrumental/behaviourist view, sees education primarily as a means to an end, often giving rise to an instructive and transmissive methodology, with an emphasis on content, information and communication, by which increased awareness and understanding, attitudinal and valuative change, leads to action towards sustainable development (Wals, 2010). Scott and Vare describe this view as ESD 1, whereby approaches 'promote' and 'inform' change in behaviours and ways of thinking according to a clearly identified need. Some see it as a case of single loop learning (Huckle, 2014; Sterling, 2003; Medel-Anonuevo, 1993), raising awareness of the necessity to do things differently and more efficiently. Its effects (e.g. reducing waste, saving energy) can be measured through reduced environmental impact (Vare \& Scott, 2007, p. 2).

The second educational perspective, which is the emancipatory (Wals, 2010) or intrinsic (Sterling, 2010) approach is a deeper, more transformative response. Freire's theories on the role of knowledge as either oppressive or emancipatory, emphasise the importance of a bottom-up approach to community transformation, in which learners are thinking critically about their own contexts, using dialogue and reflection (1970), developing action competence (Jensen \& Schnack, 1997), and allowing autonomy and self-determination (Wals, 2010, p. 45) in order to make choices in the face of uncertainty and complexity. Vare and Scott prefer to term this type of education 'ESD 2' (2007). This type of education is also sometimes described as 'double loop learning' (Sterling, 2003; Wals et al., 2009; O’Riordan \& Voisey, 1997), or second-order learning (i.e. learning about learning), whereby assumptions are questioned, and reflexivity is valued (Sterling, 2010, p. 516).

Supporting the emancipatory view is a large body of ESD literature, involving principles such as systems thinking, which tells us that a linear correlation between 
knowledge, awareness, and behaviour fails to capture the complex and contextual factors which influence people's environmental behaviours (Peters \& Wals, 2016; Lotz-Sisitka et al., 2015; Huckle \& Wals, 2015; Tilbury \& Cooke, 2005). In addition, growth in understanding of the multi-causal and multi-dimensional nature of 'Wicked' sustainability problems acknowledge that many sustainability problems defy simple policy or behavioural solutions (Lotz-Sisitka et al., 2015; O’Donoghue, 2015; Westin et al., 2013, Lang et al., 2012). This renders pre-set educational outcomes obsolete. The instrumental view also raises important questions as to the 'politics of knowledge', i.e. who is providing the information and who has most to gain from educational outcomes (Parker, 2009). With critics claiming that a top down educational process amounts to indoctrination (Jickling \& Wals, 2008; Hasslöf \& Malmberg, 2017), by co-opting ESD activities into delivering specific behaviour change objectives without duly considering power, politics and economic processes (Peters \& Wals, 2016; Huckle, 2014; Monbiot, 2016) and serving the 'Business as usual' neoliberal and marketplace worldview (Huckle \& Wals, 2015, p. 492; O’Riordan \& Voisey, 1997; Voisey et al., 1996; Sterling, 2003, p. 185; Lotz-Sisitka, 2016). Furthermore, in the context of developing countries it is important to avoid the approach described as "Deficit Development", an outlook that assumes a lack of knowledge and skills exists and must be overcome in order for development to take place. Deficit Development ignores the social capital held within resource poor communities and perpetuates a "power-gradient" from those who assume they know to those who appear to lack capacity (Taylor, 2010).

According to a growing field of researchers and practitioners, quality education is no longer based primarily on fact acquisition (Laurie et al., 2016), and the most effective ESD processes are social, collaborative, multi-disciplinary learning approaches which promote discourse, debate and reflection (Wals, 2010, 2009; Huckle, 2014; Jickling \& Wals, 2008; Lang et al., 2012; Lotz-Sisitka et al., 2015). A study carried out in Japanese schools describes typical ESD processes whereby students familiarise themselves with local problems and think about how to sustain local advantages by engaging local skills (Ichinose, 2017).

\section{Research Method}

This study used in-depth interviewing of key individuals in Indian Ocean Countries charged with ESD implementation to understand interpretations of ESD objectives (in particular UNESCO's GAP and SDG 4.7), and how these relate to the changes that the individuals wish to see on the ground. The aim was to identify if the current thinking and objectives of the Eco-Schools Indian Ocean implementing partners aligns with contemporary ESD learning theory, to ascertain if the Eco-Schools Indian Ocean programme has the potential to deliver ESD to the standard required.

Consideration of the behaviourist/emancipatory dichotomy, systems thinking, and concepts such multi-disciplinary collaboration and wicked problems had implications on the research methodology chosen. Drawing from Schon, understanding the interpretations of the implementing partners requires a methodology that allows for "Professional practice which is complex, unpredictable and messy" (1983), therefore, a qualitative research design, which uses conversation to gather stories, ideas and aspirations was used to explore the ways in which ESD is understood by the Eco-Schools IO implementing partners. Using purposeful sampling (Maxwell, 1996), eleven individuals were selected 
from National Eco-Schools Committees in participating countries (Union of Comoros, Madagascar, Mauritius, Seychelles and Zanzibar). Equal balance of Ministry and NGOs representatives interviewed, and senior or key positions of the sample, aimed to ensure relevance of research results and ability to fairly generalise the findings back to the population represented, i.e. professionals responsible for implementation of international ESD strategies on Indian Ocean SIDS. The high degree of consistency within responses amongst the implementing partners allowed the data to be analysed according to several common themes, and generalisation of conclusions drawn.

\section{Research Results}

\section{What Kind of ESD are the Implementing Partners Working Towards?}

Despite the recognition of urgent challenges being faced by the Eco-Schools Indian Ocean implementing partners, very little evidence was found of an instrumentalist and behaviourist, 'Business as usual' view of ESD, which would have been suggested by an emphasis on top down education processes with pre-set, expert-driven educational outcomes. Instead the participants emphasised the need for a "bottom-up", student led approach and there was evidence of thinking and processes consistent with an intrinsic and emancipatory view of ESD (e.g. Sterling, 2003; Jickling, 1991; Wals, 2010; Mayer \& Tschapka, 2008; Jickling \& Wals, 2008). Those interviewed emphasised ESD processes which change in the values or 'mindset' of the students. For example, in Comoros:

Focus the strategy in 'Self Change', we don't need to think about how many activities, we need to think about what is the change in each person (NGO, Comoros).

In order to achieve this deep level of change, the learning processes described resonated with principles of critical reflection and realisation, drawing on notions of 'agency' (Bengtsson, 2016, p. 81 in Lotz-Sisitka, 2017) and empowerment (Page, 1999), aiming for learners to be capable of influencing the people and environments that surround them, overcoming power relations and bringing about change;

Students need the capacity of understanding the programme, and knowing how to help others, or criticise others with their voice [...] in terms of sustainable development, and changing of the environment around them (NGO, Zanzibar).

Several people spoke in terms of this as a new approach to education, in support of the growing consensus within ESD theory that, due to the expansive nature of the change required, a transformation of education approaches is necessary.

It's a new way of education. I don't see ESD as a subject I think ESD should be a new way of teaching subjects that they are already doing in schools but with a new mindset (NGO Mauritius).

The views given suggest a shift consistent with accounts of Transformative Learning (Mezirow, 2009; Wals, 2010; Vare \& Scott, 2007; Sterling, 2010), which essentially, leads learners to recognise and modify the assumptions and beliefs behind their own understandings, values and interpretations of the world, and determine actions based on this (Mezirow, 1990). However, the notion of transformative learning is not entirely 
incompatible with the instrumentalist view, rather it can be a solution which can help to legitimise it, in the sense that the information provided is viewed critically and learners become free to make up their own minds, developing solutions based on given facts combined with their own knowledge (Sterling, 2010). Sterling believes that the process of implementing ESD itself can potentially play a transformative role in helping to reorient wider educational policy and practice towards a more holistic view (Sterling, 2003, p. 51), and it is possible to move from one perspective towards another. This was suggested in Mauritius:

In the school if the teachers are understanding that you can teach in way that changes the mind-set of the kids. Trying to create a link between the curriculum and their close environment, trying to see if they are implementing it at school. Trying to see if the school environment is changing (Ministry of Education, Mauritius).

This also supports Voisey and O'Roirdan's view of the sustainability transition whereby we move from 'Very Weak' sustainability' characterised by a subtle accommodation of sustainability principles and awareness without changes to the system, to 'Very strong sustainability' whereby there is strong policy support and comprehensive cultural shift towards sustainability, and community led initiatives are the norm (Sterling, 2003; Voisey et al., 1996)).

\section{How Can Transformative ESD be Recognised in Practice?}

Analysis of the research findings reveals that the implementing partners fully grasp and value the holistic 'whole institution approach' to ESD (Down, 2009), looking for changes within the formal teaching pedagogy and curriculum, practical and physical changes to the school buildings and grounds, and change within the wider community. The content and consistency of the answers given has allowed categorisation of the data into the four Dimensions of ESD set out in UNESCOs GAP Roadmap (2015, p. 12). The answers help to elucidate the types of transformative yet tangible changes that the implementing partners are expecting to see in each of the four dimensions of ESD.

\section{Dimension One - 'Learning Content and Pedagogy'}

The first domain of ESD according to UNESCO is 'Learning content'. However, according to the findings of this study, learning content is inextricable from pedagogy as the formal content itself is generated through a bottom-up, multi-disciplinary learning approach. For purposes of this study UNESCO's dimension One is renamed 'Learning content and pedagogy' and dimension two (previously 'Pedagogy and learning environment') is 'Learning environment', although dimension two also has a strong pedagogical element.

Almost all implementing partners mentioned the important role of the formal curriculum within the ESD process in guiding the development of knowledge and balanced understanding around sustainable development issues. Most are looking for reorientation of existing subjects around critical issues, and integration of ESD across the curriculum. Several implementing partners mentioned the need for creativity in the teaching methods 
used, and the benefits of ESD for re-energising existing curriculum subjects. For example, in Comoros:

See if teachers have adapted their teaching methods. How do the teachers integrate Eco-Schools into other subject for example in mathematics, or in Arabic? (NGO, Comoros).

The implementing partners emphasised the importance of a balance of learning content and a critical approach to sources to ensure that students are exposed to different and conflicting perspectives, helping them to adopt a more questioning and critical stance (Stevenson, 2007, Sterling, 2005). Inclusion of learning content from local and indigenous knowledge was also mentioned, entailing a revival of cultural knowledge to inform understanding of sustainable development challenges, and integration within the solutions developed to address them (e.g. Laurie et al., 2016; UNESCO, 2011). As explained in the Seychelles:

If there is an issue about water shortages in a community, look at newspaper articles, watch a video or take them out to see the leakages or issues in the community or in the schools, yes there are government resources, but what other resources and learning materials are being used? Make sure it is a mixture (Ministry of Education, Seychelles).

The concept of contextualisation of sustainable development principles is again seen as a crucial factor at the level of schools, with many of the implementing partners defining ESD itself as a process of linking their learning at school to their own environmental contexts. This reinforces concepts of sustainable citizenship and Lotz-Sisitka's 'Learning as connection' model of quality education (2013).

It will bring the change because the students will have the capacity to link their curriculum learning in schools with the physical environment surrounding them and the community (NGO, Zanzibar).

\section{Dimension Two - 'Learning Environments'}

Several implementing partners described a process whereby development of knowledge taking place within the formal curriculum is contextualised via the testing of ideas, and the learning of practical skills and everyday behaviours which address priority challenges in the school grounds and the surrounding area. Therefore, according to this study the second dimension of ESD which is 'Learning Environments' is both a pedagogical dimension and a practical one.

The implementing partners emphasised the benefits of learning outside the classroom, and engagement with real-life challenges at school level. Description of pedagogies which were consistent with place-based (Gruenewald \& Smith, 2008), problem-based learning (Wals \& Nolan, 2012), and sustainable citizenship (Huckle, 2014) encourage students to consider the social and ecological wellbeing of the places they inhabit, and their roles in shaping and nurturing them (Huckle \& Wals, 2015, 495). Most people emphasised that development of the practical projects and activities are an important part of the learning process, and lead towards a sense of ownership and responsibility. Again, it is believed that these projects should be led by the students themselves: 
It is preferable that they take a bottom up approach and they have more sense of belonging. It is better if the students themselves do the research to understand the immediate environment they are in, in the school, in the village, around the school and try to see what problems they are facing in terms of water, air, cleanliness, then do more research on the problem, try to involve the community to help them, try to involve other stakeholders, or maybe companies set up around the school to help improve the state of the village and the school (Ministry of Education, Mauritius).

It was generally accepted that for the ESD to be successful, the whole school must be aware of the programme, contributing to the success of school-based projects and adopting the new behaviours and skills in line with the priority challenges. This also has implications for issues of gender and participation, as explained in Seychelles:

Looking at individuals as an active contributor, an active participant, not because I'm a girl or I'm a boy, not because of cultural constraint. It's not only boys who are allowed to dig a hole and plant, or only girls who are allowed to collect fruits or collect water, but looking at all individuals as having the same rights and be given equal opportunity to also play an active role toward making the school a bit more sustainable, and at the same time moving this back into the community (Ministry of Education, Seychelles).

There was a lot of consistency within participant responses around the need for multiple stakeholders and community members to be involved as an integral part of ESD programmes. For the success of the programme, all implementing partners agreed that external partnerships and engagement of local individuals, experts, tradespeople, community elders can bring skills and knowledge to support real-life problems facing schools.

We need to work on more representatives to build cooperation with the programme and to unite the school and the local leaders and the communities to sustain this programme (NGO, Zanzibar).

The positive action inevitably leads to visible improvements in the physical appearance of the school. This was expressed very clearly as a desired outcome of the ESD process. Initially, focus on the physical appearance of the school could suggest a more instrumental view. However, it was justified in some interesting ways. For example, improvement of school appearance was seen to be a sign of whole-school engagement, and key to the achievement of the learning outcomes themselves in terms of creating a psychological and valuative shift within the learning environment, and having fundamental impacts to the way that education and learning as a whole are viewed, not only by students, but by the whole institution.

In Comoros many students are not motivated to go to school because their future is not bright. They don't see the point for life. If schools are more attractive because of the quality of the land, the quality of the toilets, because of the quality of the way they learn at school. My conclusion is that as the students are involved, they start to see a way forward for the future, so it is attractive for them to learn (NGO, Comoros). 
In addition, implementation of practical projects which address sustainable development challenges on the school campus often have important benefits to the students in terms of improved quality of life at school and general wellbeing. This may also have an impact on attendance.

They should be autonomous in terms of food, when they have many partnerships they can survive even if there is problems, they can have sufficient food, the children also can come into the school every day. There is less absence and more results (NGO, Madagascar).

\section{Dimension Three - 'Societal Transformation'}

The role of the wider community within the ESD process through Eco-Schools IO is seen as vital at every level and every dimension of ESD. ESD is seen to play a key role in uniting schools and communities on sustainable development issues, which can lead to individual and collaborative action and transformation (Wals, 2007, p. 17). The relationship with the community is a two-way process. Schools are seen as an important part of the community, with a role and responsibility within the wellbeing of the village or area surrounding it. A key role for ESD appears to be in supporting the development of the relationships between schools and their surrounding communities.

Because actually, the school is an institution in an area, like a post office, the school should contribute to the wellbeing of the village. The whole population should be involved (NGO Comoros).

There was general agreement that for the process to be successful, the knowledge and skills gained at school must move ultimately into action and tangible impacts in the local area. One person challenged the question 'How can we recognise these changes at school level?', saying they believe the change required is actually not in the schools.

At the end of the day the change we want to see is not in the school, it is outside the school, so the indicators that we want to build is not in the school. There are things that happen the school, but if the change happens only inside the school it is not sufficient (ISLANDS).

It is expected that as part of the ESD, there should be transference of the knowledge and skills learned at school into the wider community. Several people mentioned the important first step of students passing on their learning to family and friends, and one person went on to speculate on a deeper educational role of engaging children who don't attend school.

How can we move 'Eco-Schools' into 'Eco-Village'? We have many children who don't go to school, can we bring an eco-village where we give the opportunity to children who don't go to school a chance to discover a new way of learning. To teach them to mind and also develop new tools for developing proficiencies (NGO, Comoros).

There was also a clearly expressed need for schools to take part in wider collaborations with multiple stakeholders to solve the real-world problems facing communities. The views of the implementing partners are consistent with recent literature on collabor- 
ative and multi-disciplinary processes whereby people of various backgrounds and with different values, perspectives, knowledge and experiences are brought together to cocreate solutions for adapting to complex 'wicked' sustainability problems (Wals et al., 2009). In this sense, the central role of schools in introducing innovations which contribute to local well-being is reinforced (Iliško et al., 2017).

\section{Dimension Four - 'Learning Outcomes'}

Focussing on educational outcomes of the pedagogical processes mentioned in dimensions one to three provides an opportunity to shed some light on what might be the desirable values and attitude changes, or "new kind of thinking" (Wals, 2007, p. 17) which leads to the kinds of transformation being called for.

Several interviewees describe the deeper processes of 'Social Learning', referring to learning that occurs through processes of discussion, debate and eventually resolution, when different perspectives meet (Wals et al., 2009). Two of the implementing partners specifically mentioned conflict, corresponding with what Wals describes as the role of 'dissonance' in meaningful learning for social change (Peters \& Wals, 2016).

Conflict is quite normal because we need to understand what is running in the background of the minds of the people, they can share what they feel and unless we come together and argue about issues and come to a consensus, then we won't be able to achieve what we want to achieve in terms of national or international policies (Ministry of Education, Seychelles).

Although there was little use of the term 'critical thinking', the concept was implicit within much of the discussion around transformative ESD processes. When it was specifically mentioned, the implementing partners emphasised that critical thinking must be combined with an ability to also voice their critique and act upon it. This compliments views on critical reflection and action (Mezirow, 1990; Finlay, 2008; Huckle, 2014) and aligns with notions of agency (Lotz-Sisitka, 2016).

People always say that we should think critically but no its not enough to think critically, you have to voice your critique and act upon it. It's an indicator to the level of involvement of students in the process. Are they being fed something or are they actually participating in the process? (FEE).

Although the concept of citizenship was also not often mentioned by name, the processes described by the implementing partners, whereby critical reflection and action (Huckle, 2014) are applied to real-world situations, and skills developed to address the problems being faced by society, are believed to be an essential aspect of education for citizenship (Jeevanantham, 2005).

They have to change their manners of thinking about how to use resources, to have a good livelihood, to have a good developing economical system in the family (NGO, Madagascar).

While the implied pedagogy of Eco-Schools IO defined by the implementing partners' complements concepts of empowerment (Medel-Anonuevo, 1993; Page \& Czuba, 1999), surprisingly little mention was made of empowerment itself, the actual word being used 
only once during the interviews. The interviews also provided little evidence of a deeper critical view on global economic and political systems (Huckle, 1993), and no particular sense that the learning should be disruptive at political and structural levels (Peters \& Wals, 2016).

\section{How Can Transformative Change Be Recognised?}

This study has identified that the Eco-Schools IO implementing partners believe that transformative change is required for delivery of sustainable development targets through education. The final aim of this research project was to illuminate some signs which may be common in schools which are showing progress towards transformative change, in order to propose some possible indicators which might be used during ESD evaluation. Discussion with implementing partners during interviews helped to determine the scope for this question. It was decided to seek only to understand and identify the elements that might be recognisable during evaluation, rather than propose any quantifiable scale. Therefore, the following sections present recognisable changes as indicators, or more accurately 'progress descriptors' (Scott, 2013), as a way of gaining an understanding of progress made in ESD.

\section{Perceptions of Change (Indicator One - Learning Content and Pedagogy)}

Most of the implementing partners made reference to the need to see transformation in the mindset of students and communities, and in particular, to identify positive attitudes towards the role of Eco-Schools IO in building agency to address critical challenges. The term 'seeing the benefits' came up with surprising regularity in relation to the ability of students, teachers and community members to articulate the importance of ESD. This study proposes that ongoing evaluation can be carried out through participatory dialogues and 'most significant change' type stories (Davies \& Dart, 2005) in which members of the school community articulate what might be called their 'Perceptions of change' during the course of programme implementation. This area of evaluation will help to identify transformative change primarily within the 'Learning Content and Pedagogy' Dimension of ESD.

\section{Indicator 1(a) Students Can 'See the Benefits'}

Several people recommended providing opportunities for students to articulate their challenges and the processes behind their school projects in order to identify if the programme has been inclusive and participatory, and to allow the students to demonstrate knowledge and critical reflection on local challenges. If it is clear that they have taken responsibility for the design and implementation themselves, the existence of an emancipatory, 'bottom-up' approach, sustainable citizenship and agency is suggested. If the students can describe the changes they have seen during the course of the programme and how these changes may have benefitted the school or community, it will help us to recognise if the learning has been transformative. 


\section{Indicator 1(b) Teachers Can 'See the Benefits'}

Several people mentioned the importance of seeing transformation within the attitudes of the teachers. For example, do teachers from several different subjects understand the challenges being faced by their school and community, and believe in the potential benefits of emancipatory, bottom-up, and collaborative educational approaches to address these challenges? At the same time, do they also see the benefits of adapting teaching methods, providing a mixture of sources and incorporating place-based approaches and cultural knowledge to contextualise sustainable development concepts and add interest to existing curriculum subjects?

\section{Indicator 1(c) Parents and Other Community Members 'See the Benefits'}

The implementing partners believe that the learning in schools should involve and impact the wider school community. Evaluation which engages parents, non-teaching staff and community members around the school will help to identify how successful the school has been in bringing the community onboard and creating change in the local area. If parents and community members can see the benefits of the programme and can articulate some of the changes they have seen, it demonstrates that the wider community are aware of the programme and wider change has taken place. If the community members have been involved in the learning content or the practical projects, it may also reveal the existence of collaborative problem solving and transformative social learning, suggesting recognition of the beneficial role that schools and communities can play in addressing sustainable development challenges.

\section{There Have Been Physical Improvements to the School Grounds (Indicator Two - Learning Environments)}

The improvement of the school grounds is possibly the most obvious sign of progress with ESD. The whole school community should be working together to manage resources inside the school, and showing some innovation in the addressing of the schools' particular challenges. Rather than an evaluation of the environmental impacts themselves, which implies ESD 1 or single-loop learning (Huckle, 2014; Sterling, 2003; Vare \& Scott, 2007; Medel-Anonuevo, 1993), a clean environment, evidence of renovation, sanitation and green spaces in the school are seen as important indications of educational transformation, including whole-school and community engagement, place-based learning, sustainable citizenship and agency. Although not exclusively, change in this area closely links to the 'Learning environments' dimension of ESD.

There Have Been Physical Improvements in the Wider Community (Indicator Three Societal Transformation)

Most implementing partners gave a strong sense that the ESD process in not complete without eventually impacting the wider community around the school. By observing the state of the local area, it is possible to see if the ESD programme has reached the community, either through transference of learning, involvement of the students in real- 
world local challenges, collaborative problem solving involving community members, social learning or societal transformation.

\section{There are Improvements to School Attendance Records Over Time (Indicator Four - Learning Outcomes)}

The implementing partners mainly discussed qualitative evaluation, emphasising observation and listening to people in schools. However, the number of people who mentioned the potential of the ESD outcomes to positively affect school attendance, suggests that it would be valuable to track this over time as a quantitative indicator of transformation within schools, communities and educational systems.

\section{Discussion and Reflexivity on Results}

Despite the real and urgent challenges under which ESD professionals are working, the ideology and theory behind ESD processes and outcomes described appears to entail a shift within mainstream education towards bottom-up processes which involve discourse and critical reflection, and action based on this. ESD itself is seen as primarily a process of connecting and contextualising learning and knowledge to the real environments and communities in which they are based. Using place-based education and engagement with local sources to increase abilities of critical reflection and action on local challenges. This resonates with models such as 'Learning as connection' (Lotz-Sisitka, 2013), and reinforces the widespread movement towards multi-disciplinary approaches, which were a major theme throughout all interviews. The Eco-Schools Indian Ocean programme is seen to have a clear role to play in uniting schools and their local communities and building of collective competences. The collaborations form a two-way process which result in improved pedagogies and learning outcomes, development and transference of critical skills, and ultimately, practical improvements to conditions in the schools and local communities. Nevertheless, there was strong emphasis on formal curriculum learning and research, supporting Sterling's view that the use of behaviouralist resources can be legitimised (Sterling, 2010) and still consistent with an emancipatory approach if all information is viewed critically, and conclusions drawn based on assimilation of given facts, community perspectives and the students' own knowledge. The conclusion of this study is that Eco-Schools Indian Ocean is theoretically capable of delivering emancipatory and transformative change consistent with contemporary ESD theory, and therefore it provides an appropriate framework for delivery of international strategies such as the SDG 4.7 and the GAP.

\section{Implications for Practice}

The transformative and emancipatory paradigm revealed within this research has implications for ESD policy and practice in the Western Indian Ocean region. Future development of ESD materials for the GAP or SDG 4.7 should avoid expert driven behaviourist approaches, in favour of community-based, collaborative approaches, allowing for 'bottom-up' methods of knowledge generation, leading to social learning and action. If expert-driven information is required, it should be provided within a 
framework such as Eco-Schools which encourages critical reflection and integration with other forms of knowledge.

The explanations given during the interviews with the implementing partners offer insight to how the kinds of transformative change required might be recognisable in action within schools and communities on the ground, including stakeholders' 'Perceptions of Change', physical changes both inside and outside schools, and school attendance records. Future testing of these proposed indicators during collaborative research may provide practical evidence to support these findings.

\section{References}

Cronin, K. (2008). Transdisciplinary research (TDR) and sustainability. Institute of Environmental Science and Research Limited, 1-29.

Crossley, M., \& Sprague, T. (2014). Education for sustainable development: Implications for small island developing states (SIDS). International Journal of Educational Development, 35, 86-95. Retrieved from https://doi.org/10.1016/j.ijedudev.2013. 03.002

Davies, R., \& Dart, J. (2005). The "Most significant change” (MSC) technique. Change, $1-104$.

Down, L. (2009). Workshop 16: Teacher education in the DESD: Review and directions, UNESCO World Conference on Education for Sustainable Development. Bonn, 80-81.

Finlay, L. (2008). Reflecting on "Reflective practice.” PBPL paper 52, (January),1-27. Freire, P. C. (1970). Pedagogy of the oppressed, 2(2), ISBN 0826406114.

Gruenewald, D. A., \& Smith, G. A. (2008). Place-based education in the global age: Local diversity. New York: Lawrence Erlbaum Associates.

Harris, F., \& Lyon, F. (2014). Transdisciplinary environmental research: a review of approaches to knowledge co-production. Nexus Network Think Piece Series, 2 (November), 27.

Hasslöf, H., \& Malmberg, C. (2017). Critical thinking as room for subjectification in Education for Sustainable Development. Environmental Education Research, 4622 (March), 1-17. Retrieved from http://dx.doi.org/10.1080/13504622.2014.940854

Huckle, J. (2014). Education for sustainable citizenship; an emerging focus for education for sustainability. In Huckle, J., \& Sterling S. (Ed.). Education for sustainability. UK: Routledge, 228-243.

Huckle, J., \& Wals, A. E. J. (2015). The UN Decade of Education for Sustainable Development: business as usual in the end. Environmental Education Research, 21(3), 491-505.

Ichinose, T. (2017). An analysis of transformation of teaching and learning of Japanese Schools that significantly addressed education for sustainable development. Journal of Teacher Education for Sustainability, 19(2), 36-50.

Iliško, D., Oḷehnoviča, E., Ostrovska, I., Akmene, V., \& Salìte, I. (2017). Meeting the challenges of ESD competency - based curriculum in a vocational school setting. Discourse and Communication for Sustainable Education, 8(2), 103-113.

Jeevanantham, L. S. (2005). Why teach critical thinking? Africa Education Review, 2(1), (March), 118-129. 
Jensen, B. B., \& Schnack, K. (1997). The action competence approach in environmental education. Environmental Education Research, 3(2), (April), 163-178.

Jickling, B. (1992). Viewpoint: Why I don't want my children to be educated for sustainable development. Journal of Environmental Education, 23(4), 5-8.

Jickling, B., \& Wals, A.E.J. (2008). Globalization and environmental education: looking beyond sustainable development. Journal of Curriculum Studies, 40(1), 1-21.

Lang, D. J., et al. (2012). Transdisciplinary research in sustainability science: Practice, principles, and challenges. Sustainability Science, 7 (SUPPL. 1), 25-43.

Laurie R., Tarumi, Y., Mc Keown R., \& Hopkins, C. (2016) Contributions of education for sustainable development (ESD) to Quality Education. Journal of Education for Sustainable development, 10(2). Retrieved from http://journals.sagepub.com/doi/ abs/10.1177/0973408216661442

Lotz-Sisitka, H. (2013). Conceptions of quality and 'learning as connection': Teaching for relevance. Southern African Journal of Environmental Education, 29, 25-38.

Lotz-Sisitka, H. (2016). Reviewing strategies in/for ESD policy engagement: Agency reclaimed. The Journal of Environmental Education, 47(2), 91-103. Retrieved from http://dx.doi.org/10.1080/00958964.2015.1113915

Lotz-Sisitka, H., et al. (2015). Transformative, transgressive social learning: Rethinking higher education pedagogy in times of systemic global dysfunction. Current Opinion in Environmental Sustainability, 16, 73-80. Retrieved from http://dx.doi.org/10. 1016/j.cosust.2015.07.018

Maxwell, J. A. (1996). Qualitative research design. Newbury Park, CA: Sage.

Medel-Anonuevo, C. (1993). Women education and empowerment: Pathways towards autonomy, Hamburg. Retrieved from http://www.unesco.org/education/pdf/283_ 102.pdf

Mezirow, J. (1990). How critical reflection triggers transformative learning. Fostering Critical Reflection in Adulthood, 1-18. Retrieved from http://184.182.233.150/ rid=1LW06D9V6-26428MK-1Z64/Mezirow's chapter, How Critical Reflection Triggers TL.pdf

Monbiot, G. (2016) Neoliberalism: the deep story that lies beneath Donald Trump's triumph. The Guardian. Retrieved from https://www.theguardian.com/commentis free/2016/nov/14/neoliberalsim-donald-trump-george-monbiot

O’Donoghue, R. (2015). Think piece: Re-thinking education for sustainable development as transgressive processes of educational engagement with human conduct, emerging matters of concern and the common good. Southern African Journal of Environmental Education, 30, 7-26.

O'Riordan, T., \& Voisey, H. (1997). Beyond the early stages of the sustainability transition. Environmental Politics, 6(1), 174-177.

Parker J. (2001) Social movements and science: the question of plural knowledge systems, In After postmodernism: an introduction to critical realism. London: Athlone Press.

Peters, M. A., \& Wals, A. E. J. (2016). Transgressive learning in times of global systemic dysfunction: interview with Arjen Wals. Open Review of Educational Research, 3(1), 179-189.

Schon, D. (1983). The reflective practitioner: how professionals think in action. Basic Books. USA: The University of Michigan. 
Scott, W., \& Vare, P. (2008). Education for sustainable development - Two sides and an edge. DEA Think piece. Retrieved from http://www.tidec.org/GL\%20toolkit/ Secondary\%20handbook/2c.61\%20dea_thinkpiece_vare_scott.pdf

Scott, W. (2013). Developing the sustainable school: thinking the issues through. The Curriculum Journal, 24(2), 181-205.

Sterling, S. (2010). Learning for resilience, or the resilient learner? Towards a necessary reconciliation in a paradigm of sustainable education. Environmental Education Research, 16(5), 511-528.

Sterling, S. (2003). Whole systems thinking as a basis for paradigm change in education: Explorations in the context of sustainability. UK: University of Bath. Retrieved from http://www.bath.ac.uk/cree/sterling/sterlingtitle.pdf

Stevenson, R. B. (2007). Schooling and environmental/Sustainability Education: from discourses of policy and practice to discourses of professional learning. Environmental Education Research, 13(2), 265-285.

Taylor, J. (2010). Education for sustainable development: Perpetuating myths or bringing about meaningful change? Global Environmental Research, 187-192.

Tilbury, D., \& Cooke, K. (2005) 'A National Review of Environmental Education and its contribution to sustainability in Australia: Frameworks in sustainability'. Canberra: Australian Government Department of the Environment and Heritage and Australian Research Institute in Education for Sustainability.

UN. (2005). Annex II Mauritius Strategy for the Further Implementation of the Programme of Action for the Sustainable Development of Small Island Developing States Contents, 5-37. Retrieved from http://www.unesco.org/csi/B10/mim/mimStrategy_ English.pdf

UNESCO. (2014). Roadmap education for sustainable development, Paris. Retrieved from http://unesdoc.unesco.org/images/0023/002305/230514e.pdf

Vare, P., \& Scott, W. H. (2007). Learning for a change: Exploring the relationship between education and sustainable development, 1-6. Retrieved from http://opus. bath.ac.uk/10345/.

Voisey, H., et al. (1996). The political significance of local agenda 21: The early stages of some European experience. Local Environment, 1(1), 33-50.

Wals, A. E. J., \& Nolan, C. (2012). Shaping the education of tomorrow: 2012 Report on the UN Decade of Education for Sustainable Development (Report), France. Retrieved from http://jsd.sagepub.com/cgi/doi/10.1177/0973408213495614e

Wals, A. (2010). Message in a bottle: learning our way out of unsustainability, Wageningen University. Retrieved from https://www.groundswellinternational.org/ climate-change/message-in-a-bottle-learning-our-way-out-of-unsustainability/

Wals, A. E. J., Hoeven, van Der, N., \& Blanken, H. (2009). The acoustics of social learning. Retrieved from http://lerenvoorduurzameontwikkeling.nl/sites/default/files/ downloads/acoustics-digital_def_tcm24-290164_0.pdf

Westin, M., Hellquist, A., \& Kronlid, D. (2012). Towards urban sustainability learning from the design of a programme for multi-stakeholder. Sweden: Uppsala University.

Correspondence concerning this paper should be addressed to Olivia Copsey at the following email address: oliviacopseyesd@gmail.com 